\title{
ПСИХОЛОГІЧНА ПІДТРИМКА ОСОБИСТОСТІ: МЕТОДИ ТА ОСОБЛИВОСТІ РОБОТИ КЛІНІЧНОГО ПСИХОЛОГА
}

\author{
Кихтюк Оксана \\ Волинський національний університет імені Лесі Українки \\ м. Луцьк, Україна \\ Kuhtuik.Oksana@vnu.edu.ua \\ ORCID ID: https://orcid.org/0000-0003-1975-9925

\section{Федотова Тетяна} \\ Волинський національний університет імені Лесі Українки \\ м. Луцьк, Україна \\ Fedotova.Tetiana@vnu.edu.ua \\ ORCID ID: https://orcid.org/0000-0003-1975-9925
}

Мета статті - здійснити теоретико-методологічний аналіз понять психологічної підтримки, психологічної допомоги, психологічної реабілітації, першої психологічної допомоги (ППД), психологічного консультування; емпірично дослідити ефективність групової роботи в превентивній діяльності клінічного психолога на прикладі впровадження соціально-психологічного тренінгу 3 формування комунікативної толерантності та ненасильницького спілкування особистості.

Методи. Було використано методи теоретичного наукового пошуку аналіз, синтез, узагальнення та систематизація наукових джерел 3 питань методів роботи клінічного психолога, психологічної допомоги, підтримки, реабілітації особистості; проведено спостереження, бесіди, анкетування та статистичне опрацювання отриманих результатів до та після впровадження експериментальної програми.

Результати. Представлено головні аспекти професійної діяльності клінічного психолога. Обгрунтовано важливість здійснення головних завдань діяльності та професійної спрямованості клінічного психолога: діагностики, превентивної навчальної роботи, психопрофілактики, направлення на реабілітацію, проведення психотерапії. Проведений теоретичний аналіз понять психологічної підтримки, психологічної допомоги, психологічної реабілітації, першої психологічної допомоги (ППД), психологічного консультування засвідчив схожість та не принципову тотожність, направленість на знаходження особистісних ресурсів, на адаптацію до нових ситуативних життєвих обставин

ISSN 2308-3743 (Online), ISSN 2227-1376 (Print)

(C) Кихтюк О., Федотова Т., 2021. Ця стаття відкритого доступу на умовах CC BY-NC 4.0 
людини. Описано важливість проведення ППД. Виокремлено головні сучасні методи роботи клінічного психолога. Описано метод ненасильницького спілкування, метод «рівний-рівному». Визначено ефективність проведення психологічних та психотерапевтичних груп підтримки в роботі клінічного психолога. Емпірично засвідчено ефективність проведення соціальнопсихологічних навчально-формувальних тренінгів, базуючись на методах ненасильницького спілкування і методі «рівний-рівному».

Висновки. Проведення експериментальної програми у формі соціальнопсихологічного тренінгу показало ефективність використання еклектичного підходу у виборі психотехнічних методів для групової роботи клінічного психолога. Впровадження таких навчально-розвивальних програм являє собою психологічну допомогу та підтримку сучасної молоді на етапі становлення зрілої особистості. Перспективу прийдешніх наукових розвідок вбачаємо у розробленні та впровадженні соціально-психологічних тренінгів у роботі клінічного психолога, використовуючи еклектичний підхід у виборі психотехнічних вправ та методів психологічного впливу на особистість.

Ключові слова: психологічна підтримка, психологічна допомога, психологічна реабілітація, психологічне консультування, тренінг, методи роботи, клінічний психолог, еклектичний підхід.

\section{Kihtyuk Oksana, Fedotova Tetiana. Psychological support of personality: methods and features of work of the clinical psychologist.}

The purpose of the article is to carry out a theoretical and methodological analysis of the concepts of psychological support, psychological assistance, psychological rehabilitation, first psychological assistance (PPD), psychological counseling. Empirically study the effectiveness of group work in the preventive activities of a clinical psychologist on the example of the introduction of sociopsychological training for the formation of communicative tolerance and nonviolent communication of the individual.

Methods. Such methods of theoretical scientific research as analysis, synthesis, generalization and systematization of scientific sources on methods of work of the clinical psychologist, psychological help, support, rehabilitation of the person were used; observations, interviews, questionnaires and statistical elaboration of the obtained results before and after the implementation of the experimental program were carried out.

The results. The main aspects of the professional activity of a clinical psychologist are presented. The importance of realization of the main tasks of activity and professional orientation of the clinical psychologist is proved: diagnostics, preventive educational work, psychoprophylaxis, the direction on rehabilitation, carrying out psychotherapy. Theoretical analysis of the concepts of psychological support, psychological assistance, psychological rehabilitation, first psychological assistance (PPD), psychological counseling, shows similarity and non-fundamental identity, focus on finding personal resources, adaptation to new situational life circumstances. The importance of PPD is described. The main modern methods of 
work of the clinical psychologist are allocated. The method of nonviolent communication is described, the peer-to-peer method. The effectiveness of psychological and psychotherapeutic support groups in the work of a clinical psychologist has been determined. Empirically, the effectiveness of sociopsychological training and shaping training, based on methods of nonviolent communication, the method of peer-to-peer.

Conclusions. Conducting an experimental program in the form of sociopsychological training has shown the effectiveness of using an eclectic approach in the choice of psychotechnical methods for group work of a clinical psychologist. The introduction of such a plan of educational and developmental programs is psychological help and support for modern youth at the stage of becoming a mature person. We see the prospect of future research in the development and implementation of socio-psychological training in the work of a clinical psychologist, using an eclectic approach in the choice of psychotechnical exercises and methods of psychological impact on the individual.

Key words: psychological support, psychological help, psychological rehabilitation, psychological counseling, training, methods of work, clinical psychologist, eclectic approach.

\section{Кихтюк Оксана, Федотова Татьяна Психологическая поддержка личности: методы и особенности работы клинического психолога}

Цель статьи - осуществить теоретико-методологический анализ понятий психологической поддержки, психологической помощи, психологической реабилитации, первой психологической помощи (ППД), психологического консультирования; эмпирически исследовать эффективность групповой работы в превентивной деятельности клинического психолога на примере внедрения социально-психологического тренинга по формированию коммуникативной толерантности и ненасильственного общения личности.

Методы. Были использованы методы теоретического научного поиска анализ, синтез, обобщение и систематизация научных источников по методам работы клинического психолога, психологической помощи, поддержки, реабилитации личности; проведены наблюдения, беседы, анкетирование и статистическая проработка полученных результатов до и после внедрения экспериментальной программы.

Результаты. Представлены главные аспекты профессиональной деятельности клинического психолога. Обоснована важность осуществления главных задач деятельности и профессиональной направленности клинического психолога: диагностика, превентивная учебная работа, психопрофилактика, направление на реабилитацию, проведение психотерапии. Теоретический анализ понятий психологической поддержки, психологической помощи, психологической реабилитации, первой психологической помощи (ППД), психологического консультирования, свидетельствует сходство и не принципиальное тождество, направленность на нахождение личностных ресурсов, адаптацию к новым ситуативным жизненным обстоятельствам 
человека. Описана важность проведения ППД. Выделены главные современные методы работы клинического психолога. Описан метод ненасильственного общения, метод «равный-равному». Определена эффективность проведения психологических и психотерапевтических групп поддержки в работе клинического психолога. Эмпирически засвидетельствована эффективность проведения социально-психологических учебно-формовочных тренингов, основываясь на методах ненасильственного общения, методе «равныйравному».

Выводы. Экспериментальная программа в форме социальнопсихологического тренинга показала эффективность использования эклектического подхода в выборе психотехнических методов для групповой работы клинического психолога. Внедрение такого плана учебно-развивающих программ составляет психологическую помощь и поддержку современной молодежи на этапе становления зрелой личности. Перспектива исследований в разработке и внедрении социально-психологических тренингов в работе клинического психолога, используя эклектический подход в выборе психотехнических упражнений и методов психологического воздействия на личность.

Ключевые слова: психологическая поддержка, психологическая помощь, психологическая реабилитация, психологическое консультирование, тренинг, методы работы, клинический психолог, эклектичный подход.

Вступ. У сучасному динамічному та змінному соціумі все актуальнішим постає фах клінічного психолога, а з початком війни 3 Росією в українському суспільстві зріс запит на визначену потребу у фахівцях психологічної служби. Соціальні трансформації вимагають досвіду психологічної підтримки, допомоги фахівців професій підтримки: соціальних працівників, лікарів, психологів, реабілітологів, клінічних психологів тощо. Психологічна підтримка передбачає психологічну допомогу особистості в складних життєвих обставинах, ситуаціях, сприяє налагодженню життя та адаптації в суспільстві (Панок, Чаплак, Андреєва, 2019).

Психологічна допомога являє собою психологічну підтримку особам із використанням методів психологічної допомоги, реабілітації, психотерапії, психоконсультування (Васьківська, 2004). Психологічну реабілітацію визначають як комплекс медичних, соціальних, психологічних заходів, спрямованих на відновлення, корекцію, компенсацію порушених психічних функцій, особистих властивостей, станів та видів діяльності, систем відносин людини зі світом, що забезпечуватиме iї успішність функціонування в суспільстві (Сгорова, 2019). Інші науковці визначають це поняття як 
психічну реабілітацію (Шапарь, 2009).

Цікавим $є$ погляд учених на здатність особистості до самореабілітації. Вона полягає у відновленні, конструктивному прийнятті ситуації, переході на вищий рівень буття в доланні труднощів і спрямована на самостійну роботу людини з боротьбою зі складними життєвими обставинами, що не є кризовими. На думку Титаренко Т.М., самореабілітація уможливлюе розкриття прихованого суб'єктивного потенціалу особистості, сприяє пошуку внутрішньої цілісності, нових можливостей саморозвитку, самоздійснення, гармонійності; самореабілітація полегшує розробку індивідуальних стратегій перетворення проблемної ситуації або застарілого хронічного конфлікту, або хворобливого стану на етапи особистісного дорослішання, на етапи наближення до себе, до власної сутності (Титаренко, 1998).

Мета дослідження полягає в теоретико-методологічному аналізі понять психологічної підтримки, допомоги; висвітленні головних сучасних, ефективних методів психологічної допомоги в роботі клінічного психолога; емпіричному аналізі вивчення ефективності групової роботи.

Методи та процедура дослідження. У статті застосовано методи аналізу проблеми, синтезу, систематизації та узагальнення літератури. Проведена діагностика за методиками комунікативної толерантності В. В. Бойка та «Індекс толерантності» Г. У. Солдатової, а також спостереження і бесіда.

Обговорення результатів. Сучасні рекомендації 3 надання психологічної допомоги та підтримки завжди починаються 3 першої психологічної допомоги (далі ППД). Це визначення об’єднує систему заходів загальнолюдської допомоги особам, населенню, котрі відчувають страждання, дистрес та потребу в психологічному втручанні. Таку роботу може виконувати не лише професійний психолог, але й фахівець, ознайомлений чи навчений головним принципам надання ППД (Бондаренко, 1996; Сгорова, 2018; Бьюдженталь, 2001; Щербіна, 2009). Вона характеризується: психологічною допомогою та підтримкою у формі ненав'язливої турботи, в оцінці потреб і проблем; умінні активного слухання; в здатності заспокоїти та втішити без зайвих обіцянок; надати необхідну інформацію особам, котрі цього потребують; сприяти встановленню взаємозв'язку 3 рідними, близькими чи службами 
допомоги; надати профілактику та захист щодо шкоди самому собі. Головними завданнями ППД є надання відчуття безпеки та захисту, відновлення віри та надії в прийдешній день; зміцнення віри у власні сили, у можливість допомогти собі та іншим; встановлення можливого доступу до соціальної, фізичної та емоційної підтримки.

Варто зазначити, що не всі люди просять про ППД чи готові її прийняти, тому не варто наполягати, а просто залишатися поряд 3 такими людьми (Vogel, Wester, Larson, 2007). Вміння диференціювати потребу в ППД та необхідності в більш професійному втручанні також фахове завдання клінічного психолога. Існує чітка методична рекомендаційна база надання психологічної допомоги, зокрема військовослужбовцям (Сгорова, 2018; Бондаренко, 1996). ППД в умовах виконання службових завдань відбувається відповідно до інструкцій. Так, існує взаємозв'язок між усіма рівнями надання психологічної допомоги, а про добровільну згоду не запитують, оскільки військовослужбовець має зберігати особисту боєздатність, ресурси. А змінені стани свідомості є небезпечними не лише для нього, але й для оточення. Проте головні принципи першої психологічної допомоги: дивитися (спостерігати), слухати та направляти є незмінними (Бондаренко, 1996; Бьюдженталь, 2001). Головні завдання діяльності та професійної спрямованості клінічного психолога - це діагностика, превентивна робота, психопрофілактика, направлення на реабілітацію, проведення психотерапії, психологічна допомога постраждалим, робота в кризовому (посткризовому) стані, надання психологічного супроводу. Особи, котрі надають ППД, мають розуміти межі власних можливостей. У разі серйозних ситуацій повинні бути готові звернутись по допомогу до фахівців суміжних галузей: медиків, працівників соціальних служб, місцевого самоврядування, психіатрів, тощо (Caldas de Almeida, 2015).

Сучасний клінічний психолог може працювати чи стати сертифікованим фахівцем в таких методах психотерапії як психоаналіз, гештальт, психодрама, когнітивно-поведінкова, кліентцентрована, раціональна (роз'яснювальна), наративна, позитивна, поведінкова (біхевіоральна), каузальна, арт-терапія, логотерапія, сугестія (навіювання), аутогенне тренування, групова терапія. тілесно-орієнтована терапія. Основними формами роботи в психотерапії виділяють: індивідуальну, групову, сімейну (Бьюдженталь, 2001; Renos, 2019; Яценко, 1998). Завданнями всіх 
терапій $\epsilon$ психологічний вплив на пізнавальну, емоційну та поведінкову сферу особистості. Головна мета всіх психотерапій адаптувати особистість до нових обставин та умов життя, допомогти створити установку про себе саму як про самоактуалізовану особистість. У процесі роботи 3 клієнтом психолог здійснює три основні змінні: емпатію як здатність стати на місце іншого, зрозуміти його світ переживань; безумовне прийняття та схвалення людини, незалежно від зовнішньої поведінки; автентичність психолога, конгруентність психолога в його діях, перевага щирості, істинності поведінки (Роджерс, 1999).

Важливою ланкою роботи клінічного психолога є профілактика психічних захворювань, відома в англомовній літературі як «health education». В україномовних джерелах це поняття часто перекладають як «санітарна освіта» (лат. sanitas - здоров'я). Цей напрямок включає агітаційну роботу та інформаційну пропаганду, спрямовану на збереження, відновлення активного способу життя, працездатності, усвідомленого ставлення особистості до власного здоров'я. Ці заходи направлені не лише на індивідів, але й на групи, колективи, організації, товариства, клуби, спільноти (Перре, Бауман, 2001). Зараз найбільш розповсюдженим у роботі клінічного психолога $є$ комплекс арт-терапевтичних методів. До цієї групи відносять інструменти танцювальної, музичної, вокальної, драматичної (театральної) терапії; саморозкриття та вираження в малюнку, живописі, ліпці, скульптурі, рукоділлі, фотографуванні, казкотерапії.

Важливим $є$ використання еклектичного підходу у виборі психотехнічних методів у роботі з клієнтами відповідно до запиту, який потрібно вирішити. Психотерапевтичний ефект був засвідчений фахівцями в роботі з психотравмуючими ситуаціями (розкриття та самопізнання, розширення особистого розвитку, відновлення сил, знаходження ресурсів, відволікання та переключення уваги від негативних емоційних переживань). Ефективною вважається організація психотерапевтичних груп, груп підтримки та психологічної допомоги (Vogel, Stephen, Wester, Larson, 2007). Усі зазначені варіанти об'єднують людей із однаковими переліками проблем, питань, які вони прагнуть вирішити, кризовими життєвими обставинами. Психотерапевтичну групу веде професіонал, котрий скеровує групову динаміку та взаємодію, сприяє глибше зрозуміти, змінити неконструктивні моделі поведінки. Успішність такої групи 
залежить від керівника групи, його фахової компетенції, спеціалізації (психолог, психотерапевт, соціальний працівник) та від самих учасників групи, їхньої активності. Групи підтримки базуються більше на обміні інформацією, ресурсами, взаємодопомогою, особливо тій людині, котра не може вирішити проблему самостійно, сприяють розкриттю внутрішніх та зовнішніх ресурсів у подоланні кризового стану (Васьківська, 2004).

Сучасним методом у роботі клінічного психолога є використання «методу ненасильницького спілкування», засновником якого прийнято вважати Маршала Розенберга, автора книги «Мова життя. Ненасильницьке спілкування» (Розенберг, 2009). Головні принципи ненасильницького спілкування базуються на універсальності потреб кожної людини, стратегії їх задоволення, зосередженні на почуттях, емпатії та нівелюванні власного особистого осуду. Цей метод використовує у своїй роботі так звані відновні кола, котрі спершу використав Домінік Бартер у 1990 році. Вони базувалися на тому, що люди збиралися на форум, у межах якого, в безпечному та конструктивному середовищі вирішували конфлікти (між окремими особами, в сім'ях, організаціях, спільнотах) на принципах взаємопошани, розуміння одне одного. Відновні кола - це спосіб зцілення, прийняття відповідальності особистості за власне життя та рішення, осмислення поняття справедливості, добробуту суспільства, пропагування та поширення культури миру. Отже, групи психологічної підтримки та допомоги є тим безпечним місцем, де можна знайти психологічний комфорт, прийняття та заохочення до змін, розкриття власного потенціалу, знаходження ресурсів.

В науковій літературі існує умовна класифікація груп підтримки 3 терапевтичною метою: перша спрямована на контроль та реорганізацію поведінки (наприклад: анонімні алкоголіки); друга залучає людей, котрі пережили стресові ситуації; у третій об'єднані люди, які відчувають упередження чи дискримінацію за етнічною, расовою, класовою, гендерною приналежністю; до четвертої групи належать люди без визначеної проблеми, проте вони прагнуть до саморозвитку, покращення самоефективності, самоактуалізації власного потенціалу (Царенко, Вебер, Войтович, Гриценюк, Кочубей, Гридковець, 2018).

Метод «рівний-рівному» - популярний та відомий підхід навчання через цілісну концепцію та філософію інформування, 
консультування, підтримки та допомоги для сприяння конструктивних змін індивіда, групи, спільноти. Це принцип взаємодії людей на базі однакових ознак: вік, стать, професійна діяльність, соціально-економічне становище, стан здоров'я, спосіб життя, сексуальна орієнтація тощо. Психологічна допомога за цим принципом грунтується на тому, що підготовлені особистості 3 представників цієї групи надають психологічну підтримку в індивідуальній чи груповій формі, сприяючи зміні поведінки, стереотипів реагування, вирішення ключових поставлених проблем. Метод «рівний-рівному» усуває комунікативні бар'єри, сприяє неформальному та ненав'язливому навчанню та особистісному росту індивіда, групи. Завдяки такій взаємодії розуміються краще потреби та мотивація кожного члена групи, є можливість дізнатися незручні подробиці внутрішніх та зовнішніх конфліктів особистості. Головні методологічні принципи - адресність, безперервність, своєчасність, доступність, послідовність. Цей метод засвідчив свою ефективність в реалізації програми соціально-психологічного тренінгу для підлітків i3 формування комунікативної толерантності та навчання ненасильницького спілкування. Зміст програми складався 3 освітнього, формувального та поліфункціонального характеру 3 удосконалення навичок конструктивного діалогу, активного емпатійного слухання, асертивності, безконфліктної взаємодії в міжособистісному та професійному спілкуванні. Вибірка дослідження складалася 3 трьох тренінгових груп студентів Волинського національного університету - 32 (особи) та двох контрольних груп (34 особи). За гендерною ознакою збалансування не проводилося. Учасники були залучені шляхом добровільної участі, 3 дотриманням усіх етичних норм і принципів. Програма передбачала 8-10 занять тривалістю 1,5-2 години. Групова робота містила етапи: діагностичний (визначення рівня комунікативної та загальної толерантності особистості); вступний та навчальний iз погодження спільної роботи, прийняття правил; апробація тренінгової програми (містила психологічні техніки 3 різних методологічних підходів; завдання спрямовані на сприяння розвитку навичок ефективної комунікації, ведення конструктивного діалогу); заключний етап підбиття підсумків, підписання особистого контракту 3 дотримання ненасильницького спілкування в особистому та прийдешньому професійному житті, рефлексія. Угода 3 отриманим свідоцтвом про 
навчання у цій програмі символічно сприятиме актуалізації тих комунікативних навиків, способів порозуміння, які були засвоєні учасниками програми. Після заключного етапу було проведено повторну діагностику показників загальної комунікативної толерантності; ситуативної комунікативної толерантності; типологічної толерантності; толерантності під час професійного спілкування особистості, здійснено порівняльний аналіз. Обробка результатів здійснювалася за процедурою T-Test програмного забезпечення SPSS.

Таблиия 1

Динаміка показників комунікативної толерантності учасників програми

\begin{tabular}{|c|c|c|}
\hline $\begin{array}{c}\text { Типи комунікативної } \\
\text { толерантності особистості }\end{array}$ & $\begin{array}{c}\text { Показники } \\
\text { до групової } \\
\text { роботи }\end{array}$ & $\begin{array}{c}\text { Показники } \\
\text { після групової } \\
\text { роботи }\end{array}$ \\
\hline Загальний рівень & 81,53 & 95,96 \\
\hline Типологічний & 26,93 & 32,2 \\
\hline Ситуативний & 23,93 & 27,92 \\
\hline Професійний & 28,8 & 33,4 \\
\hline
\end{tabular}

Можна побачити, що існують позитивні показники динаміки формування комунікативної толерантності в молодих людей до проходження навчання та після. На нашу думку, це підтверджує ефективність проведення таких психопрофілактичних та розвивальних заходів 3 молодими людьми. Впровадження таких програм являє собою психологічну допомогу та підтримку сучасної молоді на етапі становлення зрілої особистості. Використання різних психотехнічних вправ засвідчує свою ефективність. Рефлексія учасників тренінгу продемонструвала важливість взаємодії групи, конструктивність обміну індивідуального досвіду між учасниками програми.

Висновки та перспективи досліджень. Методи психологічної підтримки та допомоги особистості в роботі клінічного психолога часто носять еклектичний характер та змістовність. Відповідно до запиту клієнта чи психотерапевтичної групи, фахівець має підбирати екологічні та доказові методи 3 відомих нині психотерапевтичних підходів у своїй роботі. Постає питання фаховості та меж компетенції клінічного психолога у виконанні поставлених завдань, оскільки зовнішній контроль 3 боку державних інституцій в Україні не $є$ нормативно прописаний. Перспективно розробити та впровадити 
соціально-психологічні тренінги в роботі клінічного психолога, використовуючи еклектичний підхід у виборі психотехнічних вправ та методів психологічного впливу на особистість.

\section{Література}

1. Бондаренко, О. Ф. (1996). Психологічна допомога особистості. Харків: Фоліо. 237.

2. Бьюдженталь, Дж. (2001). Искусство психотерапевта. СПб. Питер. 304.

3. Васьківська, С. В. (2004). Основи психологічного консультування: навчальний посібник. Київ: Четверта хвиля.

4. Сгорова, О. Б. (2018). Реабілітаційна психологія: курс лекцій. Слов'янськ: вид-цтво Б. І. Маторіна. 132.

5. Титаренко, Т. М. (1998). Психологічні можливості самореабілітації у складній життєвій ситуації. Реабілітамійна педагогіка на рубежі XXI століття: наук.-метод. Збірник, 142-149.

6. Царенко, Л. Вебер, Т. Войтович, М. Гриценюк, Л., Кочубей, В. Гридковець, Л. (2018). Основи реабілітаційної психології: подолання наслідків кризи. Том 2. Київ.

7. Панок, В. Г., Чаплак, Я. В., Андреєва, Я. Ф. (2019). Основи психологічної допомоги: теорія та практика психоконсультування. Чернівці: Чернівецький національний університет ім. Ю. Федьковича.

8. Перре, М., Бауман, У. (2002). Психологические аспекты реабилитации. Клиническая психология, 611-633.

9. Роджерс, К., (1999). Консультирование и психотерапия. Новейшие подходы в области практической роботы. Москва.

10. Розенберг, М. (2009). Язык жизни. Ненасильтсвенное общение. София.

11. Шапарь, В.Б. (2009). Психологічний тлумачний словник найсучасніших термінів. Харків: Прапор, 442-443.

12. Щербіна, Л. Ф. (2009). Методологія психологічної допомоги. Наукові записки Інституту ім. Г. С. Костюка АПН України. 30 (4), 342-348

13. Яценко, Т. С., (2002). Активное социально-психологическое обучение: теория, процесс, практика. Хмельницкий: НАПВУ.792.

15.David L. Vogel, Stephen R., Wester,Lisa, M. Larson (2007). Avoidance of Counseling: Psychological Factors That Inhibit Seeking Help Journal of Counceling and Development.85 (4) 2007. https://doi.org/10.1002/j.1556-6678.2007.tb00609.x

15. Deniz Fikretoglu, Marie-Louise Sharp, Amy B. Adler, Stéphanie Bélanger, David Pedlar (2011). Pathways to mental health care in active military populations across the five-eyes nations: An integrated perspective. Clinical Psychology Review In Press, Journal Pre-proof, URL: https://www.sciencedirect.com/science/article/abs/pii/S0272735821001434 
16. José Miguel Caldas de Almeida (2015). Mental health services and public mental health: challenges and opportunities. World Psichiatry. Official Journal of World Psichiatric Association (WPA) 14 (1). https://doi.org/10.1002/wps.20184

17. Renos K. Papadopoulos, John Byng-Hall Renos K (2019). Multiple Voices. Narrative in Systemic Family Psychotherapy/ London. Routledge. 256. doi: $10.4324 / 9780429477393$

\section{References}

1. Bondarenko, O.F. (1996). Psykholohichna dopomoha osobystosti [Psychological assistance of the individual]. Kharkiv: Folio [in Ukrainian].

2. Biudzhental, Dzh. (2001). Yskusstvo psykhoterapevta [The Art of the Psychotherapist]. SPb. Pyter. [in Russian].

3. Vaskivska, S. V. (2004). Osnovy psykholohichnoho konsultuvannia: navchalnyi posibnyk [Fundamentals of psychological counseling: a textbook]. Kyiv: Chetverta khvylia [in Ukrainian].

4. Iehorova, O. B. (2018). Reabilitatsiina psykholohiia: kurs lektsii [Rehabilitation psychology: a course of lectures]. Sloviansk: vyd-tstvo B. I. Matorina [in Ukrainian].

5. Tytarenko, T. M. (1998). Psykholohichni mozhlyvosti samoreabilitatsii u skladnii zhyttievii sytuatsii [Psychological opportunities for self-rehabilitation in a difficult life situation]. Reabilitatsiina pedahohika na rubezhi KhKhI stolittia: nauk.metod - Rehabilitation pedagogy at the turn of the XXI century: scientific method. Kyiv, 142-149 [in Ukrainian].

6. Tsarenko, L. Veber, T. Voitovych, M. Hrytseniuk, L., Kochubei, V. Hrydkovets, L. (2018). Osnovy reabilitatsiinoi psykholohii: podolannia naslidkiv kryzy. [Fundamentals of rehabilitation psychology: overcoming the consequences of the crisis]. Tom 2. Kyiv [in Ukrainian].

7. Panok, V.H., Chaplak, Ya. V., Andreieva, Ya. F. (2019). Osnovy psykholohichnoi dopomohy: teoriia ta praktyka psykhokonsultuvannia [Fundamentals of psychological care: theory and practice of psychoconsulting]. Chernivtsi: Chernivetskyi natsionalnyi universytet im. Yu Fedkovycha [in Ukrainian].

8. Perre, M., Bauman, U. (2002). Psykholohycheskye aspektы reabylytatsyy [Psychological aspects of rehabilitation]. Klynycheskaia psykholohyia - Clinical psychology, 611-633 [in Russian].

9. Rodzhers, K., (1999). Konsultirovanie i psihoterapiya. Noveyshie podhodyi $v$ oblasti prakticheskoy robotyi [Counseling and psychotherapy. The latest approaches in the field of practical work]. Moskva [in Russian].

10. Rozenberh, M. (2009). Yazblk zhyzny. Nenasyltsvennoe obshchenye [The language of life. Nonviolent communication]. Sofyia [in Russian].

11. Shapar, V.B. (2009). Psykholohichnyi tlumachnyi slovnyk naisuchasnishykh terminiv [Psychological explanatory dictionary of the most modern terms]. Kharkiv: Prapor, 442-443. [in Ukrainian]. 
12. Shcherbina, L. F. (2009). Metodolohiia psykholohichnoi dopomohy [Methodology of psychological care]. Naukovi zapysky Instytutu im. H. S. Kostiuka APN Ukrainy - Scientific notes of the Institute. GS Kostyuk, Academy of Pedagogical Sciences of Ukraine, 30 (4), 342-348 [in Ukrainian].

13. Iatsenko, T. S., (2002) Aktyvnoe sotsyalno-psykholohycheskoe obuchenye: teoryia, protsess, praktyka. [Social active psychological training: theory, process, practice]. Khmelnytskyi: NAPVU [in Russian].

14.Vogel, D.L., Wester, S. R., Larson, L. M. (2007). Avoidance of Counseling: Psychological Factors That Inhibit Seeking Help Journal of Counceling and Development, 85 (4). https://doi.org/10.1002/j.1556-6678.2007.tb00609.x

15. Deniz Fikretoglu, Marie-Louise Sharp, Amy B. Adler, Stéphanie Bélanger, David Pedlar (2011). Pathways to mental health care in active military populations across the five-eyes nations: An integrated perspective. Clinical Psychology Review In Press, Journal Pre-proof, URL: https://www.sciencedirect.com/science/article/abs/pii/S0272735821001434

16. José Miguel Caldas de Almeida (2015). Mental health services and public mental health: challenges and opportunities. World Psichiatry. Official Journal of World Psichiatric Association (WPA) 14 (1). https://doi.org/10.1002/wps.20184

17. Renos K. Papadopoulos, John Byng-Hall Renos K. (2019). Multiple Voices. Narrative in Systemic Family Psychotherapy. London. Routledge. 256. doi: $10.4324 / 9780429477393$

Received: 08.09.2021

Accepted: 12.10.2021 